\title{
Identification of Solid Waste Management System in Household at Palembang City
}

\author{
Hendrik Jimmyanto $^{1^{*}}$, Imron Zahri ${ }^{1}$, Hatta Dahlan ${ }^{1}$ \\ ${ }^{1}$ Environmental Management Department, Graduate School of Sriwijaya University \\ *Corresponding Author: email: tienfukhendrik@yahoo.com
}

Article history

\begin{tabular}{llll} 
Received & Received in revised form & Accepted & Available online \\
24 March 2017 & 4 May 2017 & 18 May 2017 & 30 May 2017 \\
\hline
\end{tabular}

\begin{abstract}
Increasing number of population give the impact of solid waste generation. Solid waste from household activity is about $55-80 \%$ of all waste in city which is composed of organic and inorganic waste. The important thing of solid waste management system is to know the characteristics of sources waste especially household as a step in improving solid waste management system in Palembang city. The aim of this study was to calculate solid waste generation of household in Palembang city and to identify composition and solid waste management system in household which has applied for a long time. The research method is observation survey in 3 low income household dan 3 high income household respectively numbered 20. From the result will be analysis with statistic method to see the relationship of the sample using Anova one way. The amount of weight and volume of waste generation in low income household is $0.91 \mathrm{~kg} /$ person / day and 1.51 liters / person / day. The amount of the weight and volume of waste at high home income is $0.79 \mathrm{~kg} /$ person / day and 1.63 liters / person / day. In low income household produce more organic waste than high income household.
\end{abstract}

Keywords: solid waste management system, generation, household, composition waste

\begin{abstract}
Abstrak (Indonesian): Pertambahan penduduk mengakibatkan bertambahnya jumlah timbulan sampah setiap tahunnya. Sampah padat domestik yang terbanyak dihasilkan aktivitas rumah tangga sebesar $55-80 \%$ dari total sampah. Hal terpenting dalam sistem pengelolaan sampah padat yaitu mengetahui karakteristik sumber sampah terutama pada rumah tangga sebagai langkah dalam memperbaiki sistem pengelolaan. Tujuan dari penelitian ini yaitu untuk menghitung besarnya timbulan sampah yang dihasilkan oleh rumah tangga dan mengidentifikasi komposisi sampah dan sistem pengelolaan sampah pada rumah tangga yang telah diterapkan. Metode penelitian menggunakan observasi lapangan pada 3 lokasi rumah tangga pendapatan rendah dan 3 lokasi rumah pendapatan tinggi masing-masing berjumlah 20 rumah. Dari hasil penelitian diperoleh bahwa berat dan volume timbulan sampah dari rumah tangga pendapatan rendah yaitu $0,91 \mathrm{~kg} / \mathrm{orang} /$ hari dan 1,51 liter/orang/hari. Besarnya berat dan volume timbulan sampah pada rumah tangga pendapatan tinggi yaitu $0,79 \mathrm{~kg} / \mathrm{orang} / \mathrm{hari}$ dan 1,63 liter/orang/hari. Pada rumah tangga pendapatan rendah lebih banyak menghasilkan sampah organik dibandingkan dengan rumah tangga berpenghasilkan tinggi.
\end{abstract}

\section{Kata kunci: sistem pengelolan sampah padat, timbulan sampah, rumah tangga, komposisi sampah}

\section{Introduction}

Increasing number of population levels and the rise community have gave the impact of solid waste generation in another countries. Solid waste from household activity is about $55-80 \%$ of all waste in city which is composed of organic and inorganic waste [1]. Organic waste is the waste that can decompose in nature example food waste, while inorganic waste is the waste that cannot be decomposed by nature for example plastic, paper, glass, metals and residues. One of the major cities in Indonesia, namely Palembang, there was have many problems in the solid waste management system especially in household. There are so many types of household in Palembang and each types of household produced different composition of solid waste. The important thing of solid waste management system is to know the characteristics of sources waste especially household as a step in improving solid waste management system in Palembang city [2]. Data on the waste generation was important in selecting the type of equipment, transportation and solid waste processing for solid waste management [6]. From the introduction above therefore need to research of identification of solid waste management system in household at 
Palembang city. The aim of this study was to calculate solid waste generation of household in Palembang city, to identify composition of solid waste and to identify solid waste management system in household which has applied for along time.

\section{Experimental Section}

The research location is in the Palembang city by use disproportinate stratified random sampling and amount of sample use Slovin Formula (e $=10 \%$ ). Samples were divided in two group which consist of low income households and high income household respectively numbered 20 houses that can be seen in the Table 1 below. Measurement of household waste generation is used SNI 19-39641994 methods by taking solid waste dumped in the location randomly for 3 days. From the result will be analysis with statistic metode to see the relationship of the sample using Anova one way.

Table 1. Location Research

\begin{tabular}{ccccc}
\hline No & Sample & Location of Sample & $\begin{array}{c}\text { Number } \\
\text { of Sample }\end{array}$ & $\begin{array}{c}\text { Sample } \\
\text { Code }\end{array}$ \\
\hline 1. & $\begin{array}{c}\text { Low } \\
\text { income } \\
\text { househol } \\
\mathrm{d}\end{array}$ & Jalan Ki Merogan Kecamatan Kertapati & 20 & $\mathrm{~A} 1$ \\
\cline { 3 - 5 } & Jalan Ali Gatmir Kecamatan Ilir Timur II & 20 & $\mathrm{~A} 2$ \\
\cline { 3 - 5 } & Jalan Sultan Moh Mansyur Kecamatan Ilir \\
Barat II & 20 & $\mathrm{~A} 3$ \\
\hline 2. & $\begin{array}{c}\text { Perumahan Poligon Baru Kecamatan } \\
\text { Gandus }\end{array}$ & 20 & $\mathrm{~B} 1$ \\
\cline { 3 - 5 } $\begin{array}{c}\text { High } \\
\text { househol } \\
\mathrm{d}\end{array}$ & $\begin{array}{c}\text { Perumahan Jakabaring Komplek OPI } \\
\text { Kecamatan Seberang Ulu I }\end{array}$ & 20 & $\mathrm{~B} 2$ \\
\cline { 2 - 4 } & $\begin{array}{c}\text { Perumahan Villa Sukamaju Kecamatan } \\
\text { Sako }\end{array}$ & 20 & $\mathrm{~B} 3$ \\
\hline & \multicolumn{2}{c}{ TOTAL } \\
\hline
\end{tabular}

The percentage composition of each of the components was calculated by formula :

Percentage composition of waste fraction :

$\frac{\text { weight of separated waste }}{\text { total of mixed waste sample }} \times 100 \%$

Waste generation ( $\mathrm{kg} /$ person/days $)$ :

$\frac{\text { average of total weight }}{\text { total number weight sample }}$

Volume of waste generation (liters/person/days) :

average of total volume

total number volume sample

\section{Results and Discussion}

Solid waste management system in household consist of storage bins and collecting system. The results of the observation shown that solid waste in household are mixed into one kind of solid waste.
They have not separating and sorting system into different storage bins. For solid waste management system that should be care about sorting and separating system before dump the waste and prepared the kind of storage bins such as organic and inorganic bins [3]. In low income household, some houses do not have storage bins, they use plastic bag to dump waste without sorting kind of solid waste. Kind of solid waste that they dump are organic solid waste such as food waste, inorganic waste such as cans, wrapping plastic, bottle plastics and paper.

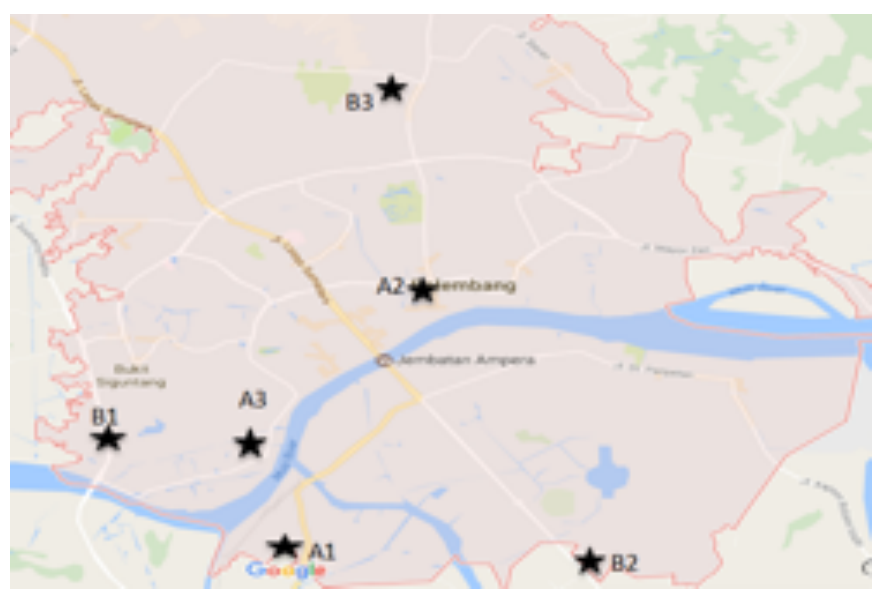

Figure 1. Map of Sample Location
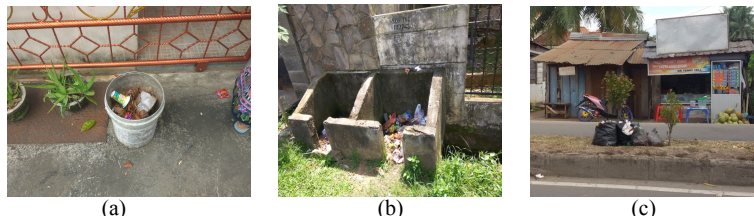

(c)

Figure 2. (a) Plastic bin, (b) Concrete bins, (c) Plastic Bags

Table 2. Storage Bins System in Location Research

\begin{tabular}{|c|c|c|c|}
\hline $\begin{array}{l}\text { Sample } \\
\text { Code }\end{array}$ & Sample Location & $\begin{array}{c}\text { Kind of } \\
\text { Household }\end{array}$ & Kind of Storage Bins \\
\hline $\mathrm{A} 1$ & Jalan Ki Merogan & \multirow{3}{*}{$\begin{array}{l}\text { Low Income } \\
\text { Household }\end{array}$} & Plastics bins and plastic bags \\
\hline $\mathrm{A} 2$ & Jalan Ali Gatmir & & Plastics bins and plastic bags \\
\hline A3 & $\begin{array}{l}\text { Jalan Sultan Moh } \\
\text { Mansyur }\end{array}$ & & Plastics bins, sacks and plastic bags \\
\hline B1 & $\begin{array}{l}\text { Perumahan Poligon } \\
\text { Baru }\end{array}$ & \multirow{3}{*}{$\begin{array}{l}\text { High Income } \\
\text { Household }\end{array}$} & $\begin{array}{l}\text { Concrete bins, Plastics bins and } \\
\text { plastic bags }\end{array}$ \\
\hline B2 & $\begin{array}{l}\text { Perumahan Jakabaring } \\
\text { Komplek OPI }\end{array}$ & & $\begin{array}{l}\text { Concrete bins, Plastics bins and } \\
\text { plastic bags }\end{array}$ \\
\hline B3 & $\begin{array}{l}\text { Perumahan Villa } \\
\text { Sukamaju }\end{array}$ & & $\begin{array}{l}\text { Concrete bins, Iron bins, Plastics bins } \\
\text { and plastic bags }\end{array}$ \\
\hline
\end{tabular}

Based on the results of the survey of storage bin system waste in household can be divided into two systems, ie:

a. Solid waste was collected in the plastic bags taken directly by invidual household to the collection place without incurring the fees. The 
collection place is usually far away from household. Low income household should dump into the collection place because they could not pay the collecting fee.

b. Solid waste was collected in the storage bins was taken by collectors service. This step should be pay the collecting fees about $10.000-$ 25.000 rupiahs per month.

The waste collection system were collected from the storage points and door to door of some households every day by using collectors service or not. Based on this research, there are so many different collection system that can be seen in the Table 3 below. This area study use 3 pattern collecting system that is :

a. direct individual collecting system is collectors service taken waste from household using truck and then delivered waste to landfill without through collecting place [4]

b. direct communal collecting system is household taken the waste by themself and delivered to collecting place [4]

c. indirect individual collecting system is the collectors service taken waste from household using cart or motorcycle and then delivered to collecting place [4]

Table 3. Exsistinc Condition of Collection System in Location Research

\begin{tabular}{|c|c|c|c|}
\hline $\begin{array}{l}\text { Sample } \\
\text { Code }\end{array}$ & Sample Location & $\begin{array}{c}\text { Kind of } \\
\text { Household }\end{array}$ & Collection System \\
\hline A1 & Jalan Ki Merogan & & $\begin{array}{l}\text { In the road side and collect by truck } \\
\text { once a day dan was delivered to } \\
\text { landfill (direct individual) }\end{array}$ \\
\hline $\mathrm{A} 2$ & Jalan Ali Gatmir & $\begin{array}{l}\text { Low Income } \\
\text { Household }\end{array}$ & $\begin{array}{l}\text { In road side, was collected by cart and } \\
\text { was delivered to collection place once } \\
\text { a day (indirect individual) }\end{array}$ \\
\hline $\bar{A} 3$ & $\begin{array}{l}\text { Jalan Sultan Moh } \\
\text { Mansyur }\end{array}$ & & $\begin{array}{l}\text { Was collected by self and was } \\
\text { delivered to collection place every } \\
\text { day (direct communal) }\end{array}$ \\
\hline B1 & $\begin{array}{l}\text { Perumahan Poligon } \\
\text { Baru }\end{array}$ & & $\begin{array}{l}\text { Was collected by cart and was } \\
\text { delivered to collection place once a } \\
\text { day (indirect individual) }\end{array}$ \\
\hline B2 & $\begin{array}{l}\text { Perumahan } \\
\text { Jakabaring Komplek } \\
\text { OPI }\end{array}$ & $\begin{array}{l}\text { High Income } \\
\text { Household }\end{array}$ & $\begin{array}{l}\text { Was collected by motorcycle and was } \\
\text { delivered to collection place once a } \\
\text { day (indirect individual) }\end{array}$ \\
\hline B3 & $\begin{array}{l}\text { Perumahan Villa } \\
\text { Sukamaju }\end{array}$ & & $\begin{array}{l}\text { Was collected by pickup car and was } \\
\text { delivered to landfill twice a day } \\
\text { (direct individual) }\end{array}$ \\
\hline
\end{tabular}

The amount of waste generation that is related to population, if the population is increase then waste generation is increase too, so this is very important to know how many household will produce the solid waste [5]. This research take the solid waste that household produce for 3 days and the total number of sample is 60 sample of low income household and 60 sample of high income household. From the statistical analysis using
Anova one way obtained that value of significant in weight generation is less than 0,05 so there are have different weight between low income household and high income household. Value of significant in volume generation is greater than 0,05 so there are not have different volume generation in this location.

Table 4. Result Anova Analysis Between 2

Location

\begin{tabular}{llrrrrr}
\hline Weight & \multicolumn{1}{c}{$\begin{array}{c}\text { Sum of } \\
\text { Squares }\end{array}$} & df & $\begin{array}{c}\text { Mean } \\
\text { Square }\end{array}$ & F & Sig. \\
& Between & 19.719 & 1 & 19.719 & 11.481 & .001 \\
& Groups & & & & & \\
& Within Groups & 614.869 & 358 & 1.718 & & \\
& Total & 634.588 & 359 & & & .052 \\
\hline Volume & Between & 18.421 & 1 & 18.421 & 3.815 & \\
& Groups & & & & & \\
& Within Groups & 1728.807 & 358 & 4.829 & & \\
& Total & 1747.228 & 359 & & & \\
\hline
\end{tabular}

Based on the research, average of weight generation in low income household (A1, A2, A3) is bigger than high income household, because in low income household there are so many organic waste which make the weight increased and the volume decreased. In high income household (B1, B2, B3) there are so many inorganic waste such as plastics, can, glass and paper which have a light weight and a large volume.

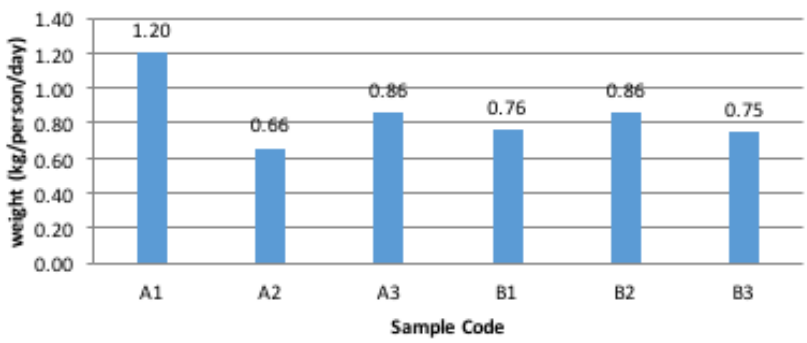

Figure 3. Graph of Weight Waste Generation

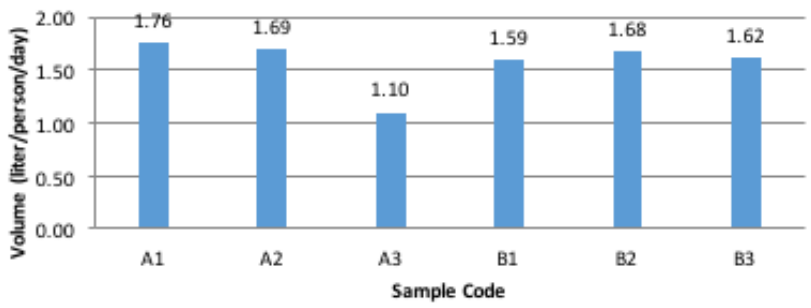

Figure 4. Graph of Volume Waste Generation

From Table 5 show that average of weight generation and volume generation between 2 kind of household. Low income household weight waste is bigger than high income household while the volume waste generation in high income household is bigger than low income household. 
Table 5. Average of Waste Generation

\begin{tabular}{clccc}
\hline $\begin{array}{c}\text { Sample } \\
\text { Code }\end{array}$ & Sample Location & $\begin{array}{c}\text { Kind of } \\
\text { Household }\end{array}$ & $\begin{array}{c}\text { Weight Waste } \\
\text { (kg/person/days) }\end{array}$ & $\begin{array}{c}\text { Volume Waste } \\
\text { (liters/person/days) }\end{array}$ \\
\hline A1 & Jln Ki Merogan & & 1.20 & 1.76 \\
A2 & $\begin{array}{l}\text { Jln Pangeran } \\
\text { Antasari }\end{array}$ & $\begin{array}{c}\text { Low income } \\
\text { household }\end{array}$ & 0.66 & 1.69 \\
A3 & $\begin{array}{l}\text { Jln Sultan M } \\
\text { Mansyur }\end{array}$ & 0.86 & 1.10 \\
\hline & Average & & 0.91 & 1.51 \\
\hline B1 & $\begin{array}{l}\text { Perumahan } \\
\text { Poligon Baru }\end{array}$ & 0.76 & 1.59 \\
B2 & $\begin{array}{l}\text { Perumahan } \\
\text { Jakabaring }\end{array}$ & $\begin{array}{c}\text { High income } \\
\text { household }\end{array}$ & 0.86 & 1.68 \\
B3 & $\begin{array}{l}\text { Komplek OPI } \\
\text { Perumahan Villa }\end{array}$ & & 0.75 & 1.62 \\
\hline & Sukamaju & & 0.79 & 1.63 \\
\hline & Average & &
\end{tabular}

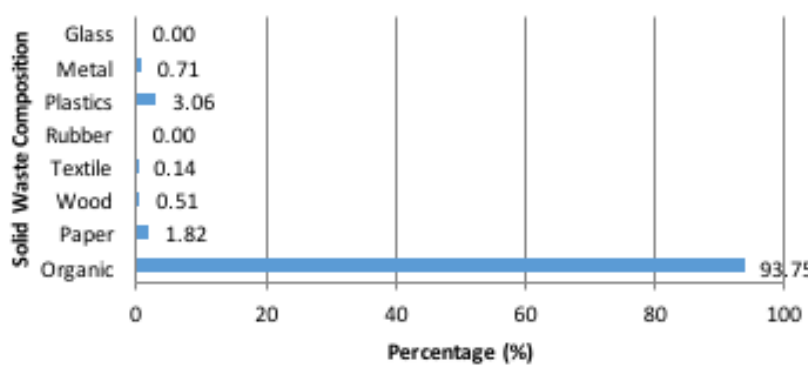

Figure 5. Composition Solid Waste in Low Income Household

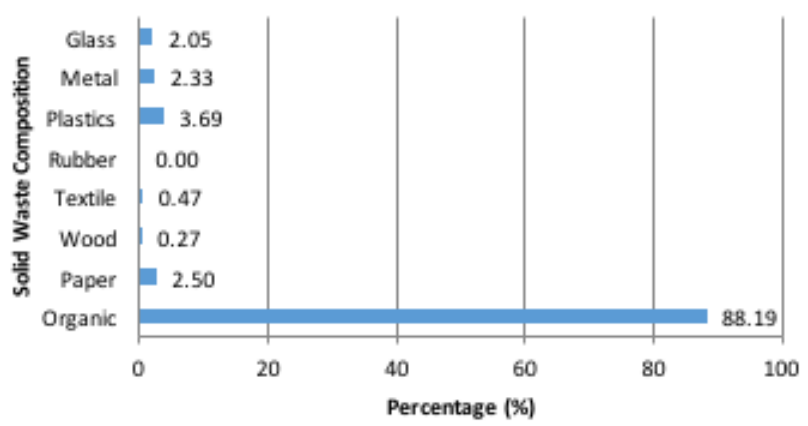

Figure 6. Composition Solid Waste in High Income Household

Of these differences are caused by activity of them. High income household more do activities using inorganic waste and discard the things that is not needed anymore, so volume generation is higher than low income household that produce a lot of organic waste that can be seen in figure 5 and figure 6. [6]

\section{Conclusion}

From this study showed that there are some differences in the solid waste management system in the household. The amount of weight and volume of waste generation in low income household is $0.91 \mathrm{~kg} /$ person / day and 1.51 liters / person / day. The amount of the weight and volume of waste at high home income is $0.79 \mathrm{~kg} /$ person / day and 1.63 liters / person / day. In low income household produce more organic waste than high income household.

\section{Acknowledgement}

Researchers say thank to those who had helped in the preparation of this study was primarily to government agencies namely Dinas Kebersihan Kota Palembang, Badan Lingkungan Hidup Kota Palembang and Bapeda Kota Palembang.

\section{References}

[1] Miezah, K., Obiri-Danso, K.,Kadar, Z.,FeiBaffoe, B., and Mensah, M.Y. " Municipal Solid Waste Characterization and Quantification As a Measure Towards Effective Waste Management in Ghana". Journal Waste Management, vol. 46, pp.15-27. 2015.

[2] Delgermaa, G. and Matsumoto, T. "A Study of Waste Management of Households in Ulaanbaatar Based on Questionnaire Surveys". International Journal of Environmental Science and Development, vol. 7(5), pp.368371.2016 .

[3] Fadhilah, A., Sugianto, H., Hadi, K, Firmandhani, S.W.,Murtini, T.W., Pandelaki, E.E. "Kajian Pengelolaan Sampah Kampus Jurusan Arsitektur Fakultas Teknik Universitas Diponegoro”. Jurnal MODUL, vol. 11(2), pp. 62-71. 2011.

[4] Sahil, J., Muhdar, M.H.I.Al., Rohman, F.,Syamsuri, I. "Sistem Pengelolaan dan Upaya Penanggulangan Sampah di Kelurahan Dufa-Dufa Kota Ternate". Jurnal BIOeduKASI, vol. 4(2), pp. 478-487. 2016.

[5] Ikhsandri, Ilmiaty, R.S., dan Putri, N.S.R. "Kajian Infrastruktur Pengolahan Sampah Di Kawasan Berkembang Jakabaring Kelurahan 15 Ulu Kota Palembang”. Jurnal Teknik Sipil dan Lingkungan, vol. 2 (1), pp. 137-145. 2014.

[6] Ruslinda, Y., Indah, S., Laylani, W. "Study Of Solid Waste Generation, Composition And Characteristic Of Domestic Solid Waste In Bukittinggi City". Jurnal Teknik Lingkungan UNAND vol. 9(1), pp. 1-12. 2012. 